\title{
5 The Crackle of the Wire: Media, Digitization, and the Voicing of Aboriginal Languages
}

\author{
Martin Thomas
}

In 1763, when the long friendship between Samuel Johnson and James Boswell was still in its infancy, their conversation turned to the poems of a clergyman named Ogilvie who was visiting London. Unlike his future biographer, Dr. Johnson had a low opinion of Ogilvie's writings, which he criticized for want of originality. "[W] hat might be called imagination in them was, to be sure, imagination once; but it is no more imagination in him than the echo is sound." Like so many of Johnson's epigrammatic utterances, the fact that we can access this curious distinction between a sound and an echo is the direct consequence of Boswell's habit of creating echoes of his own by transcribing Johnson's words (or at least his recollection of them) into his diary. So this remnant of Johnson speaking becomes uncannily self-reflexive-as Boswell might have realized when he recorded it. Enthralled as he was by the wit of Johnson, he was unpersuaded by his argument. Boswell's diary says of Ogilvie: "I cannot help, however, thinking that he has more merit than this great censor will allow." ${ }^{1}$

A Johnsonian pronouncement might seem a peculiar launching pad for a discussion about the relationship between sound recording, language, and digital technologies in Arnhem Land, a tract of Aboriginal-owned country, 97,000 square kilometers in size, situated to the east of Kakadu National Park in the far north of Australia. Readers of The Life of Samuel Johnson will recall that for all his humanist tendencies, the literary leviathan of Enlightenment England had a low opinion of traditional societies. "[O]ne set of Savages is like another," he said to Boswell as he waved dismissively at Parkinson's account of journeying with Cook. "These Voyages... will be eaten by rats and mice before they are read through. There can be little entertainment in such books." ${ }^{2}$ Yet this lack of sympathy for "savages" (and even the writers who described them), which is at least somewhat 
inconsistent coming from a man who made an ex-slave from Jamaica the chief beneficiary of his will, is among the reasons why it is so intriguing to ponder Johnson's notion of an echo being devoid of the originality or authenticity that he ascribed to sound. The publication that defined his transformation from Grub Street hack to literary eminence was A Dictionary of the English Language (1755), a work of record, trace, and echo that won him the moniker "Dictionary Johnson" and made him one of the most famous figures of his era.

Johnson's was not the first dictionary, even of English, but the thoroughness with which it furrowed English as a linguistic territory made it the lexicon par excellence, at least until the publication of the Oxford English Dictionary in the early twentieth century. The Johnson Dictionary, with its 42,000 definitions, involved the wholesale transformation of units of sound into visual signs. Now of course that transformation is not in itself special to Johnson; it is the alchemy at the heart of all writing. But the Dictionary, an icon of the encyclopedic eighteenth century, packaged and regularized the manifold vagaries of English in a way that could scarcely have been imagined by earlier generations. To invoke the resonant term used by Walter J. Ong, dictionaries enabled a new "technologizing" of the word that in an era of imperial expansion had cascading effects. It influenced the pronunciation of English, just as it facilitated the exponential growth of both its vocabulary and sphere of influence. English, as Ong argued, became a "grapholect" - "a transdialectical language formed by deep commitment to writing." ${ }^{3}$ As much as the culture of printing affected the sound of language (encouraging the standardization of grammar and diction), it also provided new avenues for the containment of social difference-a phenomenon (to use an appropriately visual metaphor) that can be counted among the many long shadows cast by the Enlightenment. The critic Bruce Johnson has argued that Samuel Johnson's exclusion of the lexicon of the underclasses was "part of their progressive criminalisation." The Dictionary was both the symbol and the instrument of a social order that "stiffened the disenfranchisement of non-literate cultures (within and beyond the nation')."4

Ong argued that oral traditions are imperiled when they clash with typographic cultures. The experience of Aboriginal Australia, like that of so many indigenous societies around the world, confirms the general substance of this claim. In the early 1990s, the Australian Institute of 
Aboriginal and Torres Strait Islander Studies, reviewing the status quo of Australian languages, reported that of the estimated 250 tongues spoken at the time of British settlement in 1788, only about ninety are still in use and of those a mere twenty are in a relatively healthy condition. Ninety per cent of Aboriginal people no longer speak an indigenous tongue. ${ }^{5}$ More recent reportage, based on 1996 data, is also pessimistic. It claims that of the 20 languages found to be healthy in 1990, a further three had become "endangered," and it predicted that unless intervention is taken, all the Aboriginal languages of Australia will be extinct by $2050{ }^{6}$ To attribute this grim history of linguistic genocide entirely to the impact of print would be simplistic. The loss of some languages was due to the outright annihilation of their speakers. But it can be said of the contact experience that the status of English as a language of the literate affected its efficacy as an instrument of coercion. That English carried textual authority affirmed the sense of entitlement and superiority of those who spoke it. (Many colonials were themselves barely literate, but this did not dent, and arguably heightened, their linguist chauvinism.) As the historian Diane Collins has remarked, Aboriginal speech was regularly typecast as "noisy jabbering" and "dreadful shrieks" in colonial accounts. Aboriginal Australians, she writes, were "portrayed as aural primitives." ${ }^{7}$ So it is not surprising that the supplanting of Aboriginal languages with English became a central objective in the "civilizing" of colonial subjects. Unlike most of the arriving Britons, Aboriginal people were typically multilingual. This was essential for conducting the trade and ceremonial relationships with neighboring communities that were standard throughout the continent. Doubtless, their grounding as polyglots affected their proficiency in acquiring English. (English speakers, in contrast, have shown little flare for learning Aboriginal tongues.) But inevitably, Aboriginal people spoke English in a manner inflected by their own linguistic heritage. From the language of their colonizers, they created a dialect, a "lingo," that in the culture of white Australia became the butt of endless jokes and caricature. When, as I have often heard, Aboriginal people utter the refrain, "Lost my land, lost my language," they cogently express this doubled sense of displacement. To convey the loss of identity and self-esteem caused by this invidious process is ultimately impossible, but its effects are evident in the frequently catastrophic condition of Aboriginal society today. 
Often unwittingly, Anglophone Australians use Aboriginal terms, or derivatives of them, in day-to-day speech. Loans from Aboriginal languages, about four hundred of which are common in modern Australian English, give the vernacular much of its presumed national flavor, as an Aboriginal man once pointed out to me as we sat by a billabong under a coolabah tree. But as a team of linguists discovered when they did interview-based research into how people perceive and define such words, public awareness that they are rooted in indigenous language is at best minimal. ${ }^{8}$ To adapt Samuel Johnson's phraseology, Aboriginal loan words have become echoes; they are frequently heard, but their origins remain unsounded.

In the mass media, and in public discourse more generally, it is remarkably rare that we hear an Aboriginal language being spoken or sung fluently on its own terms-the important moves in this direction of Aboriginal rock groups such as Yothu Yindi and the Warrumpi Band notwithstanding. The extent of this was brought home to me during a recent experience while driving through Kakadu National Park on the threshold of Arnhem Land. At a service station, a car pulled up and four young Aboriginal men got out. They bought fuel, cigarettes, soft drinks, and ice creams, loudly speaking all the while in Kunwinjku, the most common language of the west Arnhem Land region. Only when speaking to the cashier, who was nonAboriginal, did they use English. If it were Italian, Turkish, Vietnamese, or Lebanese that I had heard in a similar scenario, it would not provoke comment. For several decades after World War II, Australia opened its doors to mass immigration and to an extent the populace-although not the public culture-became linguistically diverse. Of course it is the fact that it was an Australian language that I overheard that gave cause for reflection. In the north or "Top End" of the country, and in the arid center, what I experienced is utterly normal. But most Australians, who live in the southeast of the continent, could go to their graves without having even this degree of exposure to a living Aboriginal tongue.

The history that I have summarized perhaps too briefly-in which the technologization of language has helped shape an aural landscape in which the Aboriginal presence is contained and for the most part muted-has a specific bearing on the issue that concerns us here: the relationship between digitization and the mediated voice. An indication that digitization is having a material effect upon the standing of Aboriginal language can be discerned 
in Rolf de Heer's Ten Canoes (2006), a feature film that has been rightly celebrated for breaking significant ground in Australian cinema. Its spirit of collaboration and profit-sharing arrangements with Aboriginal performers and knowledge-holders is unprecedented in the history of mainstream filmmaking. Another distinctive aspect is that Ten Canoes is the only feature to be set in Australia at a time predating the arrival of Europeans. Related to this, and particularly pertinent to this discussion, is the fact that the film is enacted in various languages indigenous to Arnhem Land, most of which fall under the umbrella term Yolyu Matha (a descriptor for the family of clan-based dialects spoken in the northeast of Arnhem Land). ${ }^{9}$ Although the film has been subtitled in English and other languages for cinema and DVD release, the drama and off-screen narration (spoken by the veteran Aboriginal actor David Gulpilil) are performed entirely in Aboriginal tongues. Most are part of the Yolyu Matha group, although Crusoe Kurddal, a lead player, speaks Kunwinjku in the film. So to say, as most commentaries have done, that the film is performed in "an" Aboriginal language is to miss a fundamental point about the polyglot quality of Arnhem Land life. Ten Canoes marks a particular milestone, as it is the first feature film to be made entirely in indigenous Australian languages.

To get a grasp of the particular achievement of de Heer and his Yolyu collaborators, and to understand the very specific role played by digitization, some historical and technological context is required. We need to consider how Arnhem Landers have been represented in time-based media, an issue that cannot be divorced from the question of how time-based media have been presented to Arnhem Landers, frequently as emblems of Westernization. An outsider could readily assume that de Heer's decision to work collaboratively on a film project with the residents of Ramingining, the settlement where Ten Canoes was shot, marks an introduction of cinema to this isolated community. Yet nothing could be further from the truth. Ten Canoes should be recognized as a recent chapter in a long and complex process of engagement, going back for at least a century, in which cameras and sound recorders have played a distinctive role in mediating the interactions between Balanda (as white people are known in this part of the country) and the communities of Arnhem Land. W. Baldwin Spencer, the first visitor to the area who had anything in the way of anthropological training, set the scene when he made films and phonographic recordings during his 1912 research trip to Oenpelli in the western part of Arnhem Land.$^{10}$ Later, 
a movie was produced during Herbert Basedow's Second Mackay Exploration Expedition in 1928 (although its whereabouts are unknown). ${ }^{11}$ Donald Thomson's outstanding photography from the 1930s-the acknowledged catalyst for Ten Canoes-I will discuss shortly. These are but a few examples.

Since the 1960s, when sound-to-film cameras became readily portable and affordable, ethnographic filmmaking has blossomed in Arnhem Land, as it has in other parts of Australia where sizable Aboriginal populations reside. Filmmakers including Ian Dunlop and Kim McKenzie worked within communities to document ceremonial traditions as well as more prosaic aspects of social life. During this period, the electronic tape recorder was also introduced, and it rapidly became a tool of trade for linguists, anthropologists, ethnomusicologists, and other fieldworkers. The tape recorder had unique attributes that suggested new possibilities for media participation, most notably its playback mechanism. ${ }^{12}$ This allowed performers to conduct on-the-spot monitoring of how they sounded-a feature that did not apply to the movie camera (although this changed with the advent of video). ${ }^{13}$ The reception of these technologies was influenced by the rate of literacy, which in Arnhem Land has never been high. This rate is due to a variety of factors: the lack of educational resources and opportunities; resistance to the authoritarianism of missionary educators (some of whom compelled children to wash their mouths out with soap if they spoke Yolyu Matha on school grounds); and the ill-suitedness of the Latin alphabet to the notation of Aboriginal phonetics. ${ }^{14}$ So it is not surprising that Aboriginal people seized upon the tape recorder as an instrument for furthering their own agendas. Examples of this can be found in the audio archives of A. P. Elkin, Australia's best known anthropologist of the mid-twentieth century, which contain several recorded missives in which senior Arnhem Landers express to Elkin their concern about the way secret-sacred information, confided to visiting researchers, had fallen into unauthorized hands. ${ }^{15}$

These attempts to regulate cultural property are indicative of a wider trend. Aboriginal people became increasingly aware that Western media could assist in the preservation of knowledge during an era of rapid change (within their own society and beyond). Yet these sorts of initiatives are seldom recognized in histories of anthropology or postcolonial critique, partly because sound archives have never attracted the same level of interest as ethnographic film and photography. As a consequence, observational practices have been privileged over the dialogic interactions that are basic to 
the ethnographic project. The dominance of sight over the other senses (trumpeted by R. Murray Schafer and later sound scholars) offers a possible explanation for this. But there is cause for a certain skepticism about the presumed evanescence of the auditory in comparison to other types of experience. As Jonathan Sterne argues, "[t]o say that ephemerality is a special quality of sound, rather than a quality endemic to any form of perceptible motion or event in time, is to engage in a very selective form of nominalism." 16

Recorded dialog between ethnographers and their subjects has in fact been extensively archived and thereby rendered "permanent." These archives are no more evanescent, or difficult to access, than films and photographs. The fact that such sources have been so comprehensively overlooked suggests to me that critics have found a comfort zone in this space of silencing. By perennially emphasizing how ethnographic subjects are constituted as objects of visual scrutiny, they turn a deaf ear to the voices of the people whom they purport to defend. The one-eyed fixation on the gaze of the camera, resting at the surface of whatever it surveys, forms a dramatic contrast to an encounter with the recorded voice, emanating, it seems, from the very inside of the speaker. The intimacy of so many recordings, augmented by the frequent transparency of the speakers' conversational strategies, brings to the forefront the question of agency. I can think of numerous examples of Aboriginal recordists who purposefully used the medium of audio to create resources for future generations. Recently I auditioned some remarkable 1970s recordings made the by Yolyu artist and political activist Wandjuk Marika. ${ }^{17}$ During a series of visits to Sydney, he spent many hours at the Australian Museum. Sitting in a quiet back room, speaking in a measured and considered English, he recorded detailed interpretations of scores of bark paintings, collected from his own country in northeast Arnhem Land. Some he had painted himself and some were done by his late father, Mawalan Marika, one of the greatest painters of the region. Wandjuk was the principal player in Ian Dunlop's film, In Memory of Mawalan (1971), a documentation of the elaborate memorial ceremony that Wandjuk coordinated as a tribute to his father. The film, still watched on video in the Marikas' home community of Yirrkala, is an example of how that dialogic exchange could be played out in the audiovisual medium of cinema. As he oversaw the preparations and the ceremonies themselves, Wandjuk was ever mindful of the filmmaker whose craft was allowing him 
to memorialize his memorial, so to speak. ${ }^{18}$ At an almost subtextual level, this contributes to the elegiac quality of the film. Ethnographic documentaries helped pave the way for film and video produced fully by Aboriginal people, some of it intended solely for Aboriginal audiences. As Eric Michaels and others have discussed, Aboriginal TV production began in the 1980s as equipment became cheaper and more user-friendly and as funding from government and other sources became available. ${ }^{19}$

The fact that Aboriginal people have assumed a degree of control over their own media image does at least complicate the history, as old as the camera, in which technologies of reproduction have been used to stigmatize and objectify those whom Westerners have classified as primitive. Indeed, as Bruno LaTour has argued, that juxtaposition of "modern" and "primitive" has been pivotal to modernity's self-definition. ${ }^{20}$ Very frequently that contrast between "the West and the Rest" is articulated by setting up a theater of technological difference. One of the subtleties that gets overlooked in this scenario is the extent to which media images provide resources for Aboriginal people to apprehend and interpret their own historical reality. Ten Canoes is a vivid example of this process, since it was inspired by the photography of Donald Thomson (1901-1970), the renowned anthropologist, photographer, and ethnological collector, who became friendly with the Yolyu during an extended residence in their country during the mid-1930s. Thomson, a fervent advocate of Aboriginal rights, was well memorialized in oral traditions. But his memory assumed new life when researchers such as the anthropologist Nicolas Peterson began to publish Thomson's photography and circulate it among the Yolyu, some of whom were inspired to visit the Museum of Victoria in Melbourne where they could view the vast array of material culture that Thomson had collected from their forebears. It was a Thomson photograph, showing men in ten canoes, that David Gulpilil singled out to de Heer as especially significant to Yolyu, and that steered the production of the film. De Heer later claimed that knowledge of traditional canoe-making had entirely disappeared in Ramingining and that the Yolnu were able to manufacture the bark vessels used in the film only by studying examples collected by Thomson. ${ }^{21}$ The latter's impact on Yolyu historical consciousness is reflected in certain structural devices that were adopted as a result of the extended liaison between the filmmaker and the community, most notably the decision to create a narrative within a narrative. In the first instance, Ten Canoes is a period drama, set at a time 
prior to European settlement during the annual hunt for eggs of the migratory magpie goose (Anseranas semipalmata). A young man named Dayindi (Jamie Gulpilil) is being told a story about another young man rather like himself-a story that is apparently set in the ancestral period of creation, the time of "the Dreaming" as it is known in English-the epoch when the land and its founding narratives were created by the ancestral beings. As much as the Dreaming is conceived as something that went before, it is nonetheless thought to exist in the here and now. The practice of ceremony, song, and storytelling brings it constantly into the present. This complex temporality is expressed in the film by the contemporary "look" of the mythical sequences, which are shot in color, many of them using aerial photography. In contrast, the "historical" component where Dayindi and his companions are hunting for eggs is shot (à la Thomson) with a fixed camera in black and white. As film critic Therese Davis explains, this was in accord with the expectations of the Yolyu whose "history as it now exists in and through the Thompson [sic] photographs needed to be depicted accurately, that is, in 'black and white."'22

All of this is evidence of the way Western media have inflected the Yolnu sense of time and history. But what of the human voice and the exclusive use of Aboriginal language in a feature film? Why suggest that David Gulpilil's mellifluous storytelling in his own tongue is somehow a product of the digital age? After all, Gulpilil has been a presence in Australian cinema for more than a generation. He made his screen debut in Walkabout (1971) after being "discovered" at the age of thirteen by the British director Nicolas Roeg. His many credits include Storm Boy (1976), Crocodile Dundee (1986), Rabbit-Proof Fence (2002), and an earlier de Heer film, The Tracker (2002). Gulpilil is easily the best-known Aboriginal actor in the history of film. The clarity with which we hear the dialog, the narration, and the highly evocative soundtrack of Ten Canoes is of course due to digital recording and studio production. But there is no technical reason why a feature film in an Aboriginal language could not have been made at the beginning of Gulpulil's career or earlier. As we have seen, ethnographic filmmakers have been doing just that for decades.

So the higher fidelity of digital audio is almost a distraction at this point. It is for quite different reasons that the computer is central to the assertion of the Yolyu that their language should be heard publicly on its own terms. To understand these reasons, it is necessary to think within the full time 
frame of modernity's trajectory, beginning back in those black-and-white days when the oral and typographic traditions encountered each othera meeting so destructive to oral societies. It continued with the arrival of cameras and recorders, and as Aboriginal people learned about these technologies and eventually began to acquire or control them, a shift occurred. In ways that were inscriptive, although they sat outside the troubled sphere of writing, these media brought techniques of encoding language and other aspects of the culture. The computer marks the current chapter in this narrative, and its distinction, as Friedrich Kittler discerned in Gramophone, Film, Typewriter (1986), is not that it added a further element to the three great strata that constitute the media of modernity (sound reproduction, moving pictures, and print). ${ }^{23}$ Rather, its triumph is one of packaging and integration. Access to what had formerly been discrete media is now integrated in a single machine; the machines themselves are integrated through adaptation of the old infrastructure of telephony.

The significance of this phenomenon lies in its twofold act of compression: the compact size (and hence the portability) of the machine and the reduction of the effective distance between machines (through instantaneity of communication). These two types of compression have transformed our experience of the computer's antecedent media. (We no longer depend on the cinema for film, the postman for mail.) For the people of Arnhem Land, whose survival as a people owes much to their geographic distance from Australia's major centers of population and political power, this change is as unmistakable as the turning of the tide. As we have seen, their contribution to media history has been extensive, but almost invariably it has resulted in the export of their cultural property to distant institutions and repositories where in many cases it has lain dormant, unseen or unheard. To appreciate how digitization is playing a role here, we must think about the logistics of how Donald Thomson's archives, and those of many other outsiders, are finding a route to their place of origin. We need to get outside the stereotype of an Aboriginal people forever bypassed by the highway of modernity, and acknowledge, as the anthropologist Melissa Hinkson argues, that these "remote" communities have been thoroughly "caught up in the telecommunications revolution which has swept the world in the past two decades. ${ }^{24}$ If the twenty-first century is broadening the bandwidth of the voices we hear in public culture, the reason is very much to do with the connectivity facilitated by digital systems. 
The dialog that is axiomatic to genuine inquiry between cultures has been extended in new directions by digitization. When the contents of media archives are dislodged and returned to their place of origin, discussions from the past can speak to the present-a process that forces the very conception of an ethnographic archive to be "reimagined," according to the musicologist Linda Barwick. Formerly, as she points out,

the sound archives' primary relationship was with the individual collector, who typically travelled to remote places to collect the recordings for deposit in the archive. Relationships between the archives and the individuals whose speech or performances were recorded were typically limited by geography, technological differentials, and sometimes language barriers. ${ }^{25}$

With the advent of facilities such online access to institutions and an increasing move toward the establishment of digital knowledge centers within Aboriginal communities, the orientation of the archive can be turned from servicing the researcher to serving the people (or their descendants) who provided the content of collections. This alters the role of the researcher as much as it affects the focus and responsibilities of the archivist.

Here I can write personally-as a historian interested in cross-cultural transactions and as a media practitioner. In an earlier age, I might have been content to write a history of Arnhem Land, or make a documentary about it, by excavating and interpreting archives in much the same manner as historians have been doing for centuries. But in an era when the prospect of transit from a colonial to a postcolonial paradigm looms as a tantalizing possibility (though not, alas, as a concrete reality), it seems not only unethical but woefully uninteresting to ignore the views of the people whose cultural heritage is encoded in those spools of tape and film. My work on northern Australia began in the archives of the Australian Broadcasting Corporation (ABC) in Sydney, where I auditioned some recordings that postdate Donald Thomson's time with the Yolnu by a little more than a decade. They were produced at the then mission settlement of Oenpelli, now a predominantly Aboriginal town called Gunbalanya in the western reaches of Arnhem Land. The people there are known as the Bininj and the most common of their many languages is Kunwinjku. The recordings I have been studying date from 1948, a time when the magnetic wire recorder, a short-lived predecessor of the tape recorder, was the machine of choice for location recording. Colin Simpson, an ABC producer (and later a wellknown travel writer), and Raymond Giles, a staff technician, liaised with 
local Bininj who performed song and ceremony for the recorder. These presentations of culture were prompted by the visit of a roving party of naturalists, anthropologists, biochemists, and photographers known as the American-Australian Scientific Expedition to Arnhem Land. ${ }^{26}$

The wire recordings were transferred to acetate discs soon after Simpson returned to Sydney. Some of the material he used in a radio documentary about the expedition, broadcast in late $1948 .{ }^{27}$ The rest of it was archived, and seems to have been left largely untouched until the discs were duplicated onto magnetic access tapes in the 1980s. These were the tapes that I auditioned-and as I did so, I copied them onto a computer where I saved them as audio files. The recordings were the thread that led me to contemporaneous film and still photography, taken by members of the Arnhem Land Expedition and held in a variety of institutions. ${ }^{28}$ By the time I traveled to west Arnhem Land in 2006, a virtual truckload of film and tape was compactly stored on my laptop.

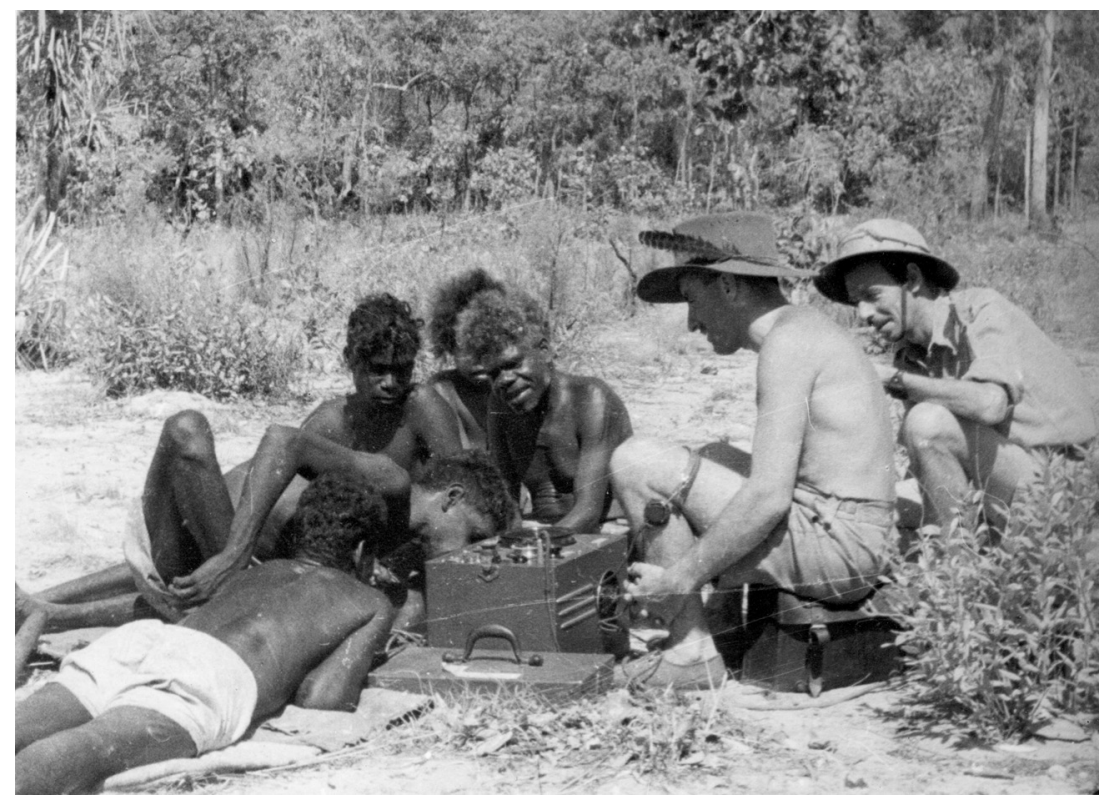

Figure 5.1

Colin Simpson (far right) and Eric Giles with unidentified men around a Pyrox wire recorder at Oenpelli,1948.

Photograph: Howell Walker. NLA MS5253/133. By permission of the National Library of Australia. 
It was Lofty Bardayal Nadjamerrek, a senior law man and renowned west Arnhem artist, who had opened the door to much of the material I gathered. Because some of it portrays restricted ceremonies, or is in other ways culturally sensitive, the archival institutions rightly insist that research can occur only with the support of traditional owners. Bardayal (born circa 1926), whose life began as a hunter-gatherer on the Arnhem Land Plateau, and who does not read or write, dictated authorization that I could access the films and recordings. This was relayed to the Australian Institute of Aboriginal and Torres Strait Islander Studies by the linguist Murray Garde, who works part of the year with Bardayal at Kabulwarnamyo, a tiny settlement within his ancestral country. I met up with Bardayal at the airport in Darwin, capital of the Northern Territory, where he had flown for a day to formalize what is known as the West Arnhem Fire Management Agreement, a partnership involving a liquid gas company, the Northern Territory government, and traditional owners of west Arnhem Land. The agreement provides Aboriginal owners with income of about $\$ 1$ million a year to implement their traditional knowledge of the country by managing bushfires and burn-offs, and thereby minimizing the release of greenhouse-producing gases. ${ }^{29}$ That the economics of power supply-a carbon emissions offset program-are providing the means for Aboriginal people to maintain connection with their ancestral country is further evidence of the complex web of relationships between antiquity and modernity being renegotiated at the present time.

Through a light haze of bushfire smoke, we flew over Kakadu and the heavily weathered sandstone of the Arnhem Land Plateau in a six-seater aircraft, bouncing down to land on a rutted slash in the forest that passes as a landing strip. Kabulwarnamyo, whose population numbers about 30, owes its position to an increase ceremony, performed for time immemorial, that involves a particular tree beside the spring that waters the settlement. In Kunwinjku the species is known as djarduk (native apple or Syzygium suborbilulare). As the term suggests, an increase ceremony encourages the abundance of living things, typically foodstuffs. In this case, the ritual involves singing a song and striking the tree with an axe. Although the djaruk at Kabulwarnamyo is recovering from fire damage, a cluster of tight little scars, formed by both stone and steel hatchets, is discernible upon the bole. The ritual is designed to increase the numbers of norne, a waspimitating fly. Bardayal is custodian of the Honey Dreaming, which explains 
his personal identification with this norne site. The norne is valued not as a comestible, but for its power of signification. Because the insect seeks native honey hives in which to lay its eggs, it can be followed in the hope that it will lead to a supply of sugarbag, as the exquisite native honey is plainly known in Aboriginal English.

Lest this conjure an Arcadian impression of life on the plateau, I should mention that a norne shares the air with signals and signifiers more typically associated with the twenty-first century. With solar panels mounted on the A-frame-and-tarpaulin structures that serve as dwellings, and a satellite dish that allows telephone service and internet connection for the communal computer, the settlement is wired up-or should I say beamed in - to the digital world. Life in the camp allows for a range of media experiences that could include, within the time frame of an hour or two, perusal of the rock art that crowds cave and boulder, a session auditioning historic recordings of Kunwinjku song (installed on the camp computer by visiting

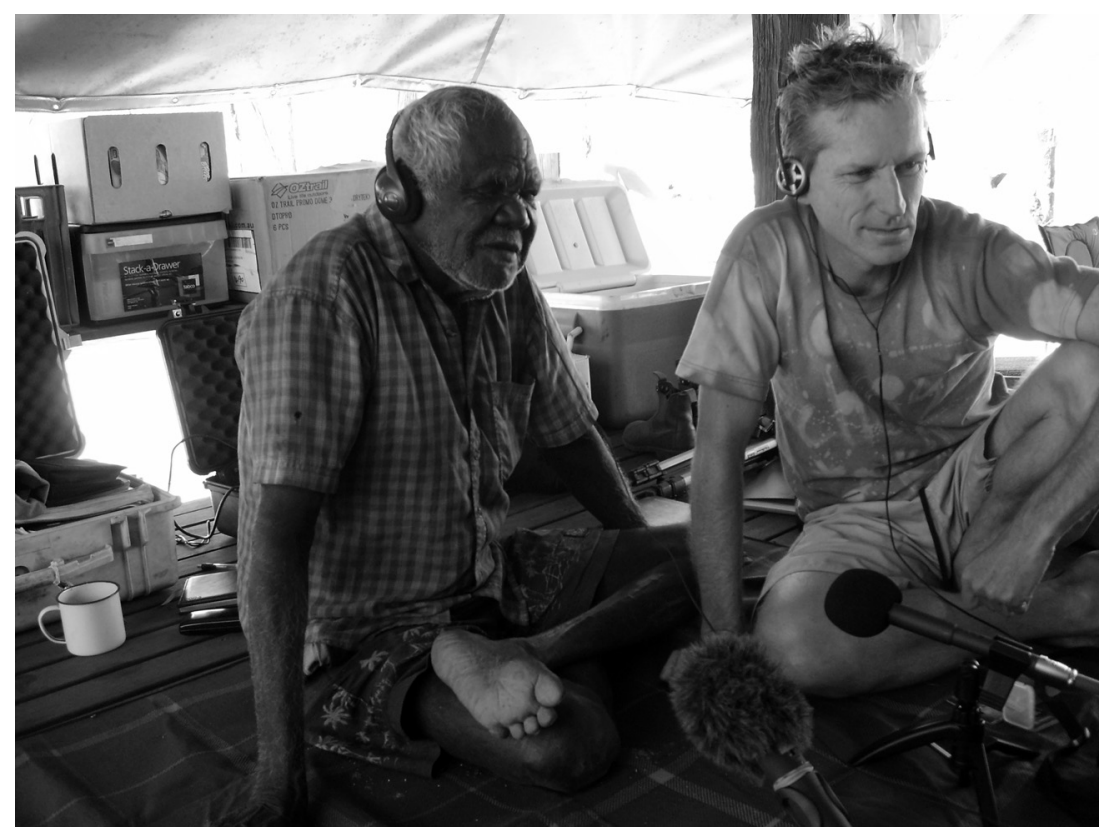

Figure 5.2

Lofty Bardayal Nadjamerrek and Murray Garde auditioning the archival recordings in 2006.

Photograph: Martin Thomas. Permission of the author. 
researchers), followed by an evening's diversion with Bruce Lee (the favored DVD at the time of my visit). This was the locale for studying the historic media images produced during the visit of the Arnhem Land Expedition in 1948. On successive days, Murray Garde and I convened discussion sessions, which we recorded. Some involved men only; others included men, women, and children. It all depended on the content of the material. While the audience gathered cross-legged on the ground, we cued iTunes or the file on the laptop and let it play.

Of the many remarkable things that occurred during that process, the most fascinating was Bardayal's response to documentation of an initiation ceremony known as Wubarr. In this culture of gender specificity, the documentation, like the ceremony itself, is out of bounds to women and children. Wubarr is the ceremony into which Bardayal and other older men in the west of Arnhem Land were first initiated as youths. The ritual has long been known to anthropologists through the work of Ronald Berndt, who observed it at Oenpelli in $1949 .{ }^{30}$ For contemporary Arnhem Landers, the significance of the documentation is heightened by the fact that Wubarr has not been performed since the 1970s. Post-World War II, it was gradually displaced by Kunapipi, an entirely different initiation ceremony, associated with the Rainbow Serpent cult. Berndt witnessed Kunapipi in northeast Arnhem Land in 1946 and made it the subject of a famous monograph. ${ }^{31}$ Although the locality of Kunapipi's origin is a matter of conjecture, all evidence attests to the rapidity with which it spread across the Top End during the middle of the twentieth century. In the Oenpelli case, the presence of the ethnographer seems to have influenced its introduction. Bardayal explained that although some residents of the mission had attended Kunapipi further east, it was performed at Oenpelli only on Berndt's request. Bardayal recalled that the appropriateness of performing a ceremony then foreign to the region was fiercely debated by senior men. But Berndt was pressing in his demand, made at a time when the authority of Balanda was not readily challenged. Bardayal stated that the request was lubricated by a substantial payment of food and tobacco to the performers-a detail that Berndt neglected to mention in his published account.

The circumstances that led to the recording of the Wubarr ceremony are another story. ${ }^{32}$ Of interest here is the way the documentation was received on the Arnhem Land Plateau-a reception that I have occasionally revisited while writing. Through headphones attached to my computer, I can 
hear the register of birdsong, the buzz and splutter of a chainsaw, and here and there the abrupt and truly awful distortion of a southerly breeze that swelled up randomly to set the microphone vibrating and coating the keyboard with dust. There is the sound of the 1948 recordings playing: the song, didgeridoo, and clap sticks, so much tinnier now than it seemed then when we were all ears, crowded around the computer. And amidst it all are the ecstatic cries of appreciation that Bardayal and others uttered in unison as a song or dance came to its conclusion. I later established that these exclamations are the typical mode of applause used at ceremonies. It was only natural that the formal gestures of appreciation should greet the documentary records.

Difficult to pick up in the field recordings, but bleedingly obvious when I return to the sound files dubbed from the ABC archives, is the crackle and interference that I like to think originate from the magnetic wire recorder, the instrument that allowed the preservation of these performances sixty years ago. Yet perhaps I am being nostalgic in connecting the crackle with the wire alone. For surely it is a composite distortion: each decaying generation in the analog chain (the steel wire, the acetate disc, the plastic tape) must have left a muddied accretion. Like static to the ear, I can hear it now, undiscriminatingly reproduced in the sequence of ones and zeroes that constitute the digital copy. Presumably, the digital reproduction has its own sound also, but this is harder to discern. The ear, and indeed the entire body, rapidly adjusts to the current notion of "high fidelity," as Barthes reminds us in "The Grain of the Voice" — his argument neatly periodized by his contemplation of how musical performance has been altered by the clarity and extended duration of a medium that now seems short and scratchy, the LP record.

Technically, it would be possible to "clean up" the 1948 recordings using digital processes and thereby eliminate much of the "crackle in the wire" (or whatever it is). In the record industry, digital recording and production are comparatively recent arrivals. The computerized processing of the sound image was first introduced for the purpose of "remastering" earlier recordings (this being a euphemism for expunging the residue of analog processes that were becoming aurally unacceptable). In a world without budgetary restraints, the Arnhem Land recordings might be similarly cleansed. Yet whether this is desirable is far from certain. The Bininj seemed perfectly happy to filter the distortion with their ears, as they did the wind and other 
distractions. And it occurred to me then that the whoosh and hiss have their own poetry; they are worth preserving, because they delineate the confluence of such dissimilar technologies and traditions. Conscious of this paradoxical melding, I hear, in the production suite that is my mind's ear, the appreciative gasps of those older men, applauding the virtuosity of long-dead dancers and singers. Somewhere along the way, their utterances find harmony with the crackle in the wire, as distinctive as the patina that coats any artifact-and equally redolent in meaning.

Many contradictions emerge when you begin to sound these echoes from the past. The belief that racial termination loomed provided the impetus for Westerners to document Aboriginal traditions. As R. H. Mathews, the early Australian anthropologist, candidly explained: the "native tribes are disappearing rapidly before the advancing tide of European population, and unless some person qualified for the task shall take up this highly important subject, the languages and the customs of an interesting primitive people will be lost to science." ${ }^{33}$ The phraseology differed over time, but the apprehension of impending disappearance was the motivation for much ethnographic recording in the twentieth century. It gave rise to the unwieldy mass that fills the media archives. Yet even as we recognize that predictions of extinction were ill founded, a further threat presents itself: the impermanence of the wax, acetate, celluloid, magnetic tape, and other media on which all this material was recorded.

Strategies for dealing with the frailty of media heritage are the subject of intense debate among the archivists who specialize in this field. An increasingly common practice is to digitize collections, even those that run to hundreds of thousands of hours of recorded data. There is no fast-tracking this process. To be faithfully reproduced, the recordings must be played in what is referred to as "real time." They must speak to the computer at the tempo at which they were made. Whether our huge ethnographic archives and collections of oral history can be preserved before they rot is a moot point. Yet there is something majestic about those spools set in ceaseless revolution, steadily disgorging memories that will otherwise be eaten by rats and mice before they are heard through. As the case study of Arnhem Land reveals, a plethora of signals converge when they meet with the computer. A temporal panorama, rooted in antiquity, though engaged with modernity in its many manifestations, is opened up by the course of this technological migration. 


\section{Acknowledgment}

I am indebted to Murray Garde for his valuable criticism and for helping me understand the linguistic diversity of Ten Canoes.

\section{Notes}

1. James Boswell, Boswell's London Journal 1762-1763 (London: William Heinemann, 1951), 289.

2. James Boswell, The Life of Johnson (Ware, Hertfordshire: Wordsworth Editions, 1999), 917.

3. Walter J. Ong, Orality and Literacy: The Technologizing of the Word London: Routledge, 2000), 8.

4. Bruce Johnson, "Voice, Power and Modernity," in Joy Damousi and Desley Deacon (eds.), Talking and Listening in the Age of Modernity: Essays on the history of sound (Canberra, Aus.: ANU E Press, 2007), 115.

5. Annette Schmidt, The Loss of Australia's Aboriginal Language Heritage (Canberra, Aus.: Aboriginal Studies Press, 1993).

6. Patrick McConvell and Nicholas Thieberger, State of Indigenous languages in Australia-2001, Second Technical Paper Series No. 2 (Natural and Cultural Heritage) (Canberra, Aus.: Department of the Environment, 2001), 2-4.

7. Diane Collins, "Acoustic Journeys: Exploration and the Search for an Aural History of Australia," Australian Historical Studies 37, no. 128 (2006), 11.

8. Gerhard Leitner and Inke Sieloff, "Aboriginal words and concepts in Australian English," World Englishes 17, no. 2 (1998), 153-169.

9. Yolnu Matha is a term meaning "people's language." It includes a number of discrete languages (some unintelligible to other Yol囚u Matha speakers) and their dialects.

10. D. J. Mulvaney and J. H. Calaby, "So Much That Is New": Baldwin Spencer, 18601929: A Biography (Carlton, Aus.: Melbourne University Press, 1985), 294.

11. The existence of the footage is known from press coverage: "[a]n excellent instructional film, 'Through Unknown Arnhem Land,' has been presented to the Imperial Institute by the British Film Institute. The film was taken by the Mackey Exploring Expedition." See F. L. Minnigerode, "London Screen Notes," New York Times, March 31, 1929, 107.

12. As I have discussed elsewhere, earlier audio technologies such as phonography and magnetic wire recording did allow playback in the field. But their size and 
expense were among the factors that generally prevented Aboriginal people from acquiring and controlling them. See my article "The Rush to Record: Transmitting the Sound of Aboriginal Culture," Journal of Australian Studies 90 (2007), 105-121.

13. Until the advent of the digital camera, the results of ethnographic still photography were usually unavailable to the people depicted. But there were exceptions to this. When photographer Axel Poignant worked in Arnhem Land in the early 1950s, he dispatched his film by plane for immediate processing and had reference prints flown back so the subjects of the photographs could see how they were being depicted. See Roslyn with Axel Poignant, Encounter at Nagalarramba (Canberra, Aus.: National Library of Australia, 1996).

14. For discussion of linguistic research and notation, see my article "Word Territory: Recording Aboriginal Language with R. H. Mathews," History Australia 5, no. 1 (2008) and William B. McGregor (ed.), Excavating Australia's Linguistic Past: Studies in the history of Aboriginal linguistics (Canberra, Aus.: Pacific Linguistics, 2008).

15. The elders are Douglas Daniels and Lazarus Lami Lami. Recordings among A. P. Elkin Papers, University of Sydney Archives, P130/Series 19/Box 136.

16. Jonathan Sterne, The Audible Past: Cultural Origins of Sound Reproduction (Durham, N.C.: Duke University Press, 2003), 18.

17. The fullest account of his life is his autobiography, itself an example of his strategic use of recording technology, as it is based on memoirs that he autonomously recorded. See Wandjuk Marika, Wandjuk Marika: Life story as told to Jennifer Isaacs (St. Lucia, Qld.: University of Queensland Press, 1995). The recordings I auditioned are in the Archives of the Australian Museum, Sydney.

18. Ian Dunlop (dir.), In Memory of Mawalan (Film Australia, 1971).

19. For an account of Aboriginal television in the Warlpiri community of Central Australia, see Eric Michaels, Bad Aboriginal Art: Tradition Media, and Technological Horizons (St. Leonards, NSW: Allen \& Unwin, 1994). Contemporary video in Arnhem Land is addressed in Jennifer Deger, Shimmering Screens: Making Media in an Aboriginal Community (Minneapolis: University of Minnesota Press, 2006).

20. Bruno Latour, We Have Never Been Modern (Cambridge, Mass.: Harvard University Press, 1993).

21. Linguist Murray Garde thinks this claim is exaggerated. He points out that relatives of actors in Ten Canoes were filmed making bark canoes in the 1990s. These vessels and associated documentation are in the collection of the Djómi Museum, Maningrida. Garde, pers. comm., June 24, 2008.

22. Therese Davis, "Remembering our ancestors: cross-cultural collaboration and the mediation of Aboriginal culture and history in Ten Canoes (Rolf de Heer, 2006)," Studies in Australasian Cinema 1, no. 1 (2007), 9. 
23. Friedrich A. Kittler, Gramophone, Film, Typewriter (Stanford: Stanford University Press, 1999).

24. Melissa Hinkson, "New Media Projects at Yuendumu: inter-cultural engagement and self-determination in an era of accelerated globalization," Continuum: Journal of Media \& Cultural Studies 16, no. 2 (2002), 207.

25. Linda Barwick, "Turning It All Upside Down . . . : Imagining a distributed digital audiovisual archive," Literary and Linguistic Computing 19, no. 3 (2004), 253-254.

26. See Colin Simpson, Adam in Ochre: Inside Aboriginal Australia (Sydney: Angus \& Robertson, 1951).

27. Colin Simpson (writer/producer), Arnhem Land Expedition, November 1948, ABC Radio Archives 83/CD/1239.

28. The major repositories are described in Martin Thomas, "Taking Them Back: Archival media in Arnhem Land today," Cultural Studies Review 13, no. 2 (2007), 20-37.

29. Details at http://www.atns.net.au/agreement.asp?EntityID=3638 (accessed February 20,2008$)$.

30. Ronald M. Berndt and Catherine H. Berndt, Man, Land \& Myth in North Australia: The Gunwinggu People (Sydney: Ure Smith, 1970).

31. Ronald M. Berndt, Kunapipi: A Study of an Australian Aboriginal Religious Cult (New York: International Universities Press, 1951).

32. See Thomas, "Taking Them Back."

33. R. H. Mathews, "Languages of the New England Aborigines, New South Wales," Proceedings of the American Philosophical Society 42 (1903), 249-250. 